\title{
Firearm Availability and Homicide Rates across 26 High- Income Countries
}

\author{
David Hemenway, PhD, and Matthew Miller, MD, MPH, ScD
}

Background: Among developed nations, the United States has the highest rate of civilian gun ownership, and the highest homicide rate. We examine whether the United States is merely an exception, or if a relationship between gun availability and homicide exists across all developed nations.

Methods: Homicide rates for the early 1990s come from 26 of 27 of the highly industrialized or high-income countries with greater than 1 million population as classified by the World Bank. Two common proxies for gun availability are used, the percentage of suicides with a firearm, and the"Cook index," the average of the percentage of suicides with a firearm and the percentage of homicides with a firearm.

Results: In simple regressions (no control variables) across 26 high-income nations, there is a strong and statistically significant association between gun availability and homicide rates.

Conclusion: Across developed countries, where guns are more available, there are more homicides.

Keywords: Firearms, Guns, Homicide, International.

J Trauma. 2000;49:985-988.
O f all developed nations, the United States has the most privately owned guns, and the highest rates of homicide. Approximately two thirds of murder victims in the United States are killed with a gun.

Is gun availability associated with homicides across all developed nations, or is the United States just an exceptional case? Across developed nations, the most widely cited international study examined 14 countries. ${ }^{1}$ Gun ownership information was obtained from comparable telephone interviews. The rate of gun homicide, and the total homicide rate was significantly correlated with levels of gun ownership; there was no significant correlation between nongun homicide and gun ownership. As the authors of that study note, at least three methodologic considerations limit the inferences that can be drawn from the results: only a small number of countries was sampled, the countries selected for inclusion were not a random sample of developed nations, and homicide data were for years earlier than the data on gun ownership rates.

Our study extends this previous work by analyzing contemporaneous data on firearm availability and homicide rates among 96\% (26 of 27) of all the countries with more than 1 million inhabitants defined by the World Bank as high income or highly industrialized.

Submitted for publication February 14, 2000.

Accepted for publication August 9, 2000.

Copyright (C) 2000 by Lippincott Williams \& Wilkins, Inc.

From the Harvard Injury Control Research Center, Harvard School of Public Health, Boston, Massachusetts.

This research was supported in part by grants from the Centers for Disease Control and Prevention, the Joyce Foundation, the Robert Wood Johnson Foundation, and the Center on Crimes, Communities and Culture of the Open Society Institute.

Address for reprints: David Hemenway, PhD, Director, Harvard Injury Control Research Center, Harvard School of Public Health, 677 Huntington Avenue, Boston, MA 02115; email: hemenway@hsph.harvard.edu.

\section{MATERIALS AND METHODS}

Using data reported by researchers at the Centers for Disease Control and Prevention (CDC), ${ }^{2}$ countries were selected in accordance with the World Bank's definition of nations that are highly industrialized or have high-income economies (1992 gross national product per capita $>\$ 8,356$ ). Each year the World Bank classifies all nations by income based on their gross national product. Of the nations with populations greater than 1 million included in the 1994 World Development Report, ${ }^{3} 27$ were classified as highly industrialized or as having high-income economies. Twenty-six (96\%) of these 27 countries provided data for analysis. Over $76 \%$ provided data for 1993 or 1994; the rest gave data for 1990,1992 , or $1995 .^{2}$ The countries, the year for which the data were provided, populations, and overall homicide death rates are given in Table 1.

We analyze the association between firearm availability and total homicide rates in both the 26 high-income or highly industrialized nations described above, as well as in the sample of 36 countries compiled by the CDC researchers, ${ }^{2}$ which includes an additional 10 "upper middle income nations" that provided data (53\% of the 19 upper middle income countries that were asked provided the requested data).

As a proxy for gun availability, we use the percentage of suicides with a firearm for the independent variable; we also use a second proxy, the average of the percentage of homicides and suicides attributable to firearms (Cook index). The first measure is highly correlated with the percentage of households reporting gun ownership in studies both of 170 US cities $(r=0.86)^{4}$ and across 16 developed nations $(r=$ $0.91) .^{5}$ This measure has often been used as a proxy for gun availability. ${ }^{4,6-8}$ The Cook index has been validated for urban patterns of regional gun ownership with data from surveys of residents $(r=0.91) .^{9}$ The Cook index has also been validated at the regional level in the United States with 


\section{Table 1 Homicide Rates for 26 High-Income Countries}

\begin{tabular}{|c|c|c|c|c|}
\hline Country & Year & $\begin{array}{c}\text { Population } \\
\text { (in thousands) }\end{array}$ & $\begin{array}{c}\text { Total Homicide } \\
\text { Rate per 100,000 }\end{array}$ & $\begin{array}{l}\text { Suicides with a } \\
\text { Firearm (\%) }\end{array}$ \\
\hline Northern Ireland & 1994 & 1,642 & 6.82 & 15.9 \\
\hline Israel & 1993 & 5,261 & 2.32 & 26.1 \\
\hline Italy & 1992 & 56,764 & 2.25 & 13.9 \\
\hline Scotland & 1994 & 5,132 & 2.24 & 2.7 \\
\hline Taiwan & 1994 & 21,086 & 1.78 & 1.7 \\
\hline Singapore & 1994 & 2,930 & 1.71 & 1.2 \\
\hline New Zealand & 1993 & 3,458 & 1.47 & 16.7 \\
\hline Belgium & 1990 & 9,967 & 1.41 & 13.4 \\
\hline Switzerland & 1994 & 7,021 & 1.32 & 26.4 \\
\hline Sweden & 1993 & 8,718 & 1.30 & 13.3 \\
\hline France & 1994 & 57,915 & 1.12 & 24.7 \\
\hline Netherlands & 1994 & 15,382 & 1.11 & 3.0 \\
\hline Kuwait & 1995 & 1,684 & 1.01 & 3.6 \\
\hline Norway & 1993 & 4,324 & 0.97 & 29.0 \\
\hline Spain & 1993 & 39,086 & 0.95 & 5.5 \\
\hline Ireland & 1991 & 3,525 & 0.62 & 9.6 \\
\hline Japan & 1994 & 124,069 & 0.62 & 0.2 \\
\hline England/Wales & 1992 & 51,429 & 0.55 & 4.3 \\
\hline
\end{tabular}

Data from Krug et al., $1998 .^{2}$

General Social Survey-based estimates of handgun ownership $(r=0.96)$ and for 21 states that reported household firearm ownership levels on Behavioral Risk Factor Surveillance surveys $(r=0.83){ }^{10}$ International data for the 26 developed countries were not available on rates of handgun ownership or handgun fatalities. Analyses are conducted using both the homicide rate and the natural log of the homicide rate, the latter better approximating a normal distribution.

\section{RESULTS}

Across the 26 developed countries, the simple correlation coefficient between the gun availability proxy and the total homicide rate is 0.69 ; the relationship is significant at $p<$ 0.000. Using the Cook index, the correlation coefficient is
0.74 and the relationship is significant at $p<0.000$ (Table 2). The relationship between gun availability and homicide is similar for both forms of the dependent variable - the total homicide rate or the natural log of the homicide rate.

Dropping the United States from the analysis, the results remain significant when the Cook index is used $(p<0.01)$ but not when the percentage of suicides with a firearm is used as the gun proxy (Table 2). The firearm homicide rate is very strongly associated with the Cook index; the nonfirearm homicide rate shows no statistically significant correlation (not shown).

The one country defined by the World Bank as high income or highly industrialized that might not be considered as "developed" is Kuwait. Eliminating Kuwait from the analysis does not alter the findings (not shown). Northern Ireland

Table $2 \beta$ Coefficients (with Significance Levels) and Correlation Coefficients in Regressions of Gun Availability and Homicide for 26 High-Income Countries, 1990s ${ }^{a}$

\begin{tabular}{|c|c|c|c|c|}
\hline \multirow{2}{*}{$\begin{array}{c}\text { Dependent Variable: } \\
\text { Homicide Rate for } 26 \\
\text { Developed Nations }\end{array}$} & \multicolumn{2}{|c|}{$\begin{array}{l}\text { Gun Availability Proxy } 1 \\
\text { (\% Suicides Using Gun) }\end{array}$} & \multicolumn{2}{|c|}{ Gun Availability Proxy 2 (Cook Index) } \\
\hline & $\beta$ & Cor & $\beta$ & Cor \\
\hline Crude rate & $10.1(0.000)$ & 0.69 & $9.2(0.000)$ & 0.74 \\
\hline Excluding US & $2.9(0.236)$ & 0.25 & $4.9(0.003)$ & 0.57 \\
\hline Natural log of rate & $2.9(0.001)$ & 0.61 & $2.9(0.000)$ & 0.70 \\
\hline Excluding US & $1.8(0.112)$ & 0.32 & $2.2(0.005)$ & 0.55 \\
\hline
\end{tabular}

$\beta, \beta$ coefficients; Cor, correlation coefficients.

${ }^{a}$ Raw data from Krug et al., 1998. ${ }^{2}$ 
Table 3 及 Coefficients (with Significance Levels) and Correlation Coefficients in Regressions of Gun Availability and Homicide, for 36 Upper Middle Income and High-Income Countries, 1990s ${ }^{a}$

\begin{tabular}{|c|c|c|c|c|}
\hline \multirow{2}{*}{$\begin{array}{l}\text { Dependent Variable: } \\
\text { Homicide Rate for } 36 \\
\text { Developed and Lesser } \\
\text { Developed Nations }\end{array}$} & \multicolumn{2}{|c|}{$\begin{array}{l}\text { Gun Availability Proxy } 1 \\
\text { (\% Suicides Using Gun) }\end{array}$} & \multicolumn{2}{|c|}{ Gun Availability Proxy 2 (Cook Index) } \\
\hline & $\beta$ & Cor & $\beta$ & Cor \\
\hline Excluding US & $9.0(0.324)$ & 0.17 & $11.8(0.092)$ & 0.29 \\
\hline Natural log of rate & $2.7(0.018)$ & 0.39 & $2.8(0.002)$ & 0.49 \\
\hline Excluding US & $2.3(0.095)$ & 0.29 & $2.6(0.012)$ & 0.42 \\
\hline
\end{tabular}

$\beta, \beta$ coefficient; Cor, correlation coefficients.

${ }^{a}$ Raw data from Krug et al., 1998. ${ }^{2}$ The 10 additional countries that are added to the 26 high-income countries are Brazil, Mexico, Estonia, Argentina, Portugal, Slovenia, Greece, Hungary, Mauritius, and South Korea. Brazil, Mexico, and Estonia have about two to three times the murder rate of the United States.

was in the midst of "the troubles" or civil war in 1994. If Northern Ireland is eliminated from the analysis, the results remain statistically significant (not shown).

Weighting the 26 observations by the population of the country increases the association between firearm availability and homicide (not shown), since some of the largest countries are at the extremes. The United States has many guns and many homicides, whereas Japan and England have few guns and few homicides.

When all 36 countries for which Krug et al. ${ }^{2}$ obtained data are considered (the 26 high-income or highly industrialized and 10 upper middle income nations), the results often remain significant (Table 3). For example, the natural log of the homicide rate is positively associated with both measures of firearm availability $(p<0.05)$, and the crude homicide rate is significantly associated with the Cook index $(p<0.05)$ (Table 3).

\section{DISCUSSION}

Results from our simple regressions of 26 developed nations show a highly significant positive correlation between total homicide rates and both proxies for gun availability. When we use the Cook index, the correlation is particularly strong, and results remain statistically significant when the United States is excluded.

It is, of course, possible that the findings could be "explained" by other variables; our regressions contain only one independent variable, a measure of gun availability. However, by looking exclusively at industrialized and high-income nations, we do control, in part, for some social and economic variables.

Cross-sectional studies like ours do not provide information about causality. For example, a relationship between variables $x$ and $y$ may be attributable to $x$ causing $y, y$ causing $x$, or a third variable affecting both.

Our results are consistent with the Killias results. ${ }^{1}$ Compared with our study, Killias used a measure of rates of household gun ownership - comparable household survey results - but included fewer nations. Our results are also consistent with many ecological studies of the United States, which find that in areas with more guns there are more homicides, ${ }^{6,8,11-13}$ and with case-control studies that find a gun in the home to be a risk factor for homicide victimization and the perpetration of murder. ${ }^{14-17}$

Currently, there is no "gold standard" for the measure of gun availability. Like our measure, the percentage of households with a firearm is only a crude proxy of gun availability for use in homicide, for it tells nothing about the number of guns per household, the types (e.g., handguns) or calibers of the guns, the storage of the guns, the carrying of the guns, or the ease with which urban adolescents can obtain handguns. In addition, surveys typically underrepresent poor people (e.g., households without telephones), and individuals who own guns illegally may not report them. It also appears that, at least in the United States, women living in two-adult households with guns often do not know that there is a gun in their home. ${ }^{18,19}$ Fortunately, household gun ownership and both Cook index and the percentage of suicides with a gun are highly correlated, suggesting that they are providing information about similar constructs.

Another limitation of our study is that the measures of homicide and firearm availability may vary from country to country because of differences in the specificity and sensitivity of the surveillance systems. For example, different countries may not have comparable definitions of homicide (e.g., whether guerilla or terrorist activities should be included). Problems with data comparability and accuracy are particularly acute for nonindustrialized nations. On this basis alone, it is expected that including industrialized and nonindustrialized nations in a single analysis, despite the larger number of observations, could reduce the power to find a statistically significant association between the variables.

Social scientists are taught that it is generally inappropriate to include industrialized and nonindustrialized countries in the same analysis, because their social, political, and economic structures are usually quite different; confounding by cultural factors is likely to be more substantial when both industrialized and nonindustrialized nations are included in the study. For example, in the sample of 36 nations, $71 \%$ of the firearm deaths in the high-income countries were sui- 
cides, whereas $72 \%$ of the firearm deaths in the upper middle income countries were homicides. ${ }^{2}$

One study mixed together the 10 nonindustrialized nations (including Estonia, Mexico, Brazil, Mauritius, and Slovenia) with the 26 high-income nations in an analysis of firearms and homicide. ${ }^{4}$ A priori, the results would be expected to be biased toward the null. Yet even including both developed and less developed nations in the analysis, the association between the homicide rate and the gun availability measures are positive and usually statistically significant.

In our analysis, we find, for industrialized countries, a very strong and highly significant association between gun availability levels and total homicide rates. The relationship holds even though the number of observations is fairly small $(\mathrm{n}=26)$ and the measures of gun availability are only proxies. The relationship does not seem to be attributable entirely to the United States - which has more guns and more homicides than other developed nations - because the results often hold when the United States is excluded from the analysis. More guns are associated with more homicides across industrialized countries.

\section{REFERENCES}

1. Killias M. International correlations between gun ownership and rates of homicide and suicide. Can Med Assoc J. 1993;148:17211725.

2. Krug EG, Powell KE, Dahlberg LL. Firearm-related deaths in the United States and 35 other high- and upper-middle-income countries. Int J Epidemiol. 1998;27:214-221.

3. World Bank. World Development Report. New York: Oxford University Press; 1994:251-252.

4. Kleck G. Targeting Guns: Firearms and their Control. New York: Aldine de Gruyter; 1997.
5. Killias M. Gun ownership, suicide, and homicide: an international perspective. In: del Frate AA, Zvekic U, van Dijk JJJ, eds. Understanding Crime: Experiences of Crime and Crime Control. Rome: UNICRI; 1993:289-303.

6. Lester D. Firearm availability and the incidence of suicide and homicide. Acta Psychiatr Belg. 1988;88:387-393.

7. Lester D. Gun control, gun ownership and suicide prevention. Suicide Life Threat Behav. 1988;18:176-180.

8. Lester D. Relationship between firearm availability and primary and secondary murder. Psychol Rep. 1990;67:490.

9. Cook PJ. The technology of personal violence. In: Tonry M, ed. Crime and Justice. Vol 14. Chicago: University of Chicago Press; 1991.

10. Miller M, Azrael D, Hemenway D. Firearm availability and unintentional firearm deaths. Accid Anal Prev. In press.

11. Brearly HC. Homicide in the United States. Chapel Hill, NC: University of North Carolina Press; 1932.

12. Seitz ST. Firearms, homicide, and gun control effectiveness. Law Soc Rev. 1972;6:595-614.

13. Brill S. Firearm Abuse: A Research and Policy Report. Washington, DC: Police Foundation; 1977.

14. Kellermann AL, Rivara FP, Rushforth NB, et al. Gun ownership as a risk factor for homicide in the home. N Engl J Med. 1993; 329:1084-1091.

15. Cummings P, Koepsell TD, Grossman DC, et al. The association between the purchase of a handgun and homicide or suicide. Am J Public Health. 1997;87:974-978.

16. Rowland J, Holtzhauer F. Homicide involving firearms between family, relatives and friends in Ohio: an offender-based case-control study. Am J Epidemiol. 1989;130:825-825.

17. Kleck G, Hogan M. A national case control study of homicide offending and gun ownership. Soc Probl. 1999;46:275-293.

18. Ludwig J, Cook PJ, Smith TW. The gender gap in reporting household gun ownership. Am J Public Health. 1998;88:1715-1718.

19. Azrael D, Miller M, Hemenway D. Are firearms stored safely in households with children? It depends on whom you ask. Pediatrics. 2000;106:E31. 